(Received: Mei 2018; Reviewed: Agustus-2018; Published: Oktober 2018)

DOI: http://dx.doi.org/10.26858/pembelajar.v2i2.5974

\title{
Analisis Kebutuhan Materi Ajar Membaca Bipa A1 Dengan Pendekatan Deduktif di SD D'Royal Moroco
}

\author{
Siti Ayu Ningsih ${ }^{\mathrm{a}}$, Yumna Rasyid ${ }^{\mathrm{a}}$, Liliana Muliastuti ${ }^{\mathrm{b}}$ \\ ${ }^{a}$ Universitas Negeri Jakarta, Jalan Rawamangun Muka, Jakarta, Indonesia \\ ${ }^{\text {b} U n i v e r s i t a s ~ N e g e r i ~ J a k a r t a, ~ J a l a n ~ R a w a m a n g u n ~ M u k a, ~ J a k a r t a, ~ I n d o n e s i a ~}$ \\ Email: sitiayuningsih92@yahoo.co.id
}

\begin{abstract}
Abstrak: Penelitian ini bertujuan untuk mendeskripsikan: 1) kebutuhan materi ajar membaca bagi siswa BIPA (Bahasa Indonesia Penutur Asing) tingkat A1 dengan pendekatan deduktif di Sekolah Dasar D'Royal Moroco Integrative Islamic School, dan 2) kondisi materi ajar membaca yang selama ini digunakan di sekolah tersebut. Metode penelitian yang digunakan merupakan tahapan eksplorasi dari penelitian pengembangan. Berdasarkan hasil observasi, analisis dokumen, wawancara, dan tes dapat dijabarkan bahwa sekolah tersebut belum memiliki silabus dan materi ajar khusus bagi para siswa BIPA. Sedangkan di sekolah tersebut memiliki cukup banyak siswa BIPA. Hal ini menjadikan pentingnya pengembangan materi ajar membaca BIPA tingkat A1 untuk segera dilakukan. Dalam pendekatan deduktif, materi ajar yang dikembangkan, harus memiliki urutan penyajian sebagai berikut: 1) kaidah pada bagian awal, 2) diikuti contoh-contoh relevan, dan 3) latihan yang memadai. Dalam kaitannya dengan penggunaan materi bagi siswa SD yang masih tergolong anak-anak, maka materi ajar yang dikembangkan juga harus memuat ilustrasi yang menarik.
\end{abstract}

Kata Kunci: Analisis kebutuhan, materi ajar, membaca, BIPA A1, deduktif

Abstract: This study aims to describe: 1) the need of reading material for BIPA (Indonesian Language for Foreign Speakers) students at A1 level using deductive approach in D'Royal Moroco Integrative Islamic Elementary School, and 2) the condition of reading material that has been used in the school. This research was the exploration stage of research and development method. Based on the observations, documents analysis, interviews and tests result, can be elaborated that the school did not have any syllabus and specific teaching materials for BIPA. While the school had quite a lot of BIPA students. This situasion needs immediate action of developing reading teaching material for BIPA at A1 level. By following the deductive approach, the teaching material should have: 1) begins with the concept introduction, 2) followed by relevant examples, and 3) contains of adequate practice. It is also should containing relevant and interesting illustrations.

Keywords: Need analysis, teaching material, reading, BIPA A1, deductive

(c) (1) () (2018 -Pembelajar Universitas Negeri Makassar. Ini adalah artikel dengan akses terbuka dibawah licenci CC BY-NC-4.0 (https://creativecommons.org/licenses/by-nc/4.0/).

\section{PENDAHULUAN}

Bahasa Indonesia merupakan mata pelajaran wajib untuk diajarkan di sekolah formal sebagaimana dimandatkan dalam Undangundang No. 24 Tahun 2009 tentang Bendera, Bahasa, dan Lambang Negara, serta Lagu Kebangsaan. Keberadaannya di sekolah, tidak sebatas pada sekolah nasional berstatus negeri maupun swasta. Sekolah berstatus Internasional yang berubah nama menjadi Satuan Pendidikan Kerjasama (SPK) juga diwajibkan untuk mengajarkan bidang studi Bahasa Indonesia sebagaimana tertuang dalam Peraturan Menteri Pendidikan dan Kebudayaan Republik Indonesia Nomor 31 Tahun 2014 (tentang kerjasama penyelenggaraan dan pengelolaan pendidikan oleh lembaga pendidikan asing dengan lembaga pendidikan di Indonesia).

Dalam kaitannya dengan pemberlakuan Peraturan Menteri tersebut, maka setiap siswa yang bersekolah di SPK akan mempelajari bahasa Indonesia. Perbedaannya, terletak pada status wajib atau pilihan yang dipengaruhi oleh kewarganegaraan siswa yang bersekolah di sekolah tersebut. Siswa berkewarganegaraan 
Indonesia wajib mengikuti bidang studi Bahasa Indonesia sedangkan siswa asing dapat memilih untuk mengikuti atau pun tidak mengikuti.

Sebagai penutur asing yang mempelajari bahasa Indonesia di Indonesia, seharusnya siswa asing mendapatkan kelebihan berdasarkan pendapat yang menyatakan bahwa pembelajaran bahasa asing yang ideal terjadi apabila proses belajar bahasa itu dilakukan dalam suatu budaya, negara, atau tempat bahasa itu digunakan. Kontak langsung dengan masyarakat penutur bahasa asli serta hal-hal yang berkaitan dengan bahasa tersebut akan membuat bahasa tersebut mudah dipahami (Rivai, 2010). Inilah faktor pendukung yang penting dalam keberhasilan belajar suatu bahasa.

Berdasarkan pendapat tersebut, seharusnya siswa BIPA di SD D'Royal Moroco Integrative Islamic School mendapatkan keuntungan sebagaimana dipaparkan Rivai. Akan tetapi, faktanya tidak sesederhana anggapan tersebut. Masalah muncul ketika siswa BIPA di SD D'Royal Moroco Integrative Islamic School keadaannya sangat dinamis. Tidak semua siswa BIPA berada di kelas rendah seperti kelas 1 atau kelas 2. Mereka tersebar di semua kelas karena tahun masuk para siswa BIPA ke sekolah tersebut tidak selalu sama. Terkait erat dengan masa kedatangan mereka ke Indonesia. Masalah lainnya yaitu, siswa BIPA mendapatkan pengajaran Bahasa Indonesia dengan standar yang sama dengan siswa non-BIPA. Mereka ditempatkan dalam kelas yang sama dengan kurikulum, materi ajar, sumber belajar, dan proses evaluasi yang sama saat proses pengajaran bahasa Indonesia berlangsung.

Siswa BIPA dan non-BIPA tentu saja memiliki karakteristik yang berbeda dalam mempelajari bahasa Indonesia. Siswa non-BIPA umumnya telah mengetahui konsep bahasa Indonesia sedangkan siswa BIPA yang merupakan penutur bahasa asing hanya mengetahui konsep-konsep bahasa ibunya. Dengan demikian, jika terdapat perbedaan konsep antara bahasa ibunya dan bahasa Indonesia yang sedang dipelajarinya, maka diperlukan suatu materi ajar yang tepat untuk membantu mereka agar terampil berbahasa Indonesia. Materi ajar, didefinisikan sebagai segala deskripsi sistematis dari teknik-teknik dan latihan-latihan yang akan digunakan dalam kegiatan pemelajaran yang mencakup rencana pengajaran, namun dapat diakomodasi dalam bentuk buku, paket alat bantu audiovisual, permainan, atau kegiatan lainnya yang terjadi di dalam kelas (Brown, 1995).

Perbedaan pengetahuan konsep bahasa antara penutur asli bahasa Indonesia dan penutur asing membuat standar kompetensi yang harus dicapai keduanya juga menjadi berbeda. Pemerintah telah menetapkan standar kompetensi lulusan untuk pengajaran Bahasa Indonesia bagi penutur asing dalam Permendikbud Nomor 27 tahun 2017. Peraturan tersebut membagi level kompetensi dalam 7 tingkat. Adapun Bagi siswa SD dapat mengikuti BIPA tingkat 1 sampai dengan tingkat 2 . Untuk tingkat 1 ini sama dengan tingkat A1 dalam CEFR (Common European Framework of Reference for Language). CEFR sendiri menjadi salah satu acuan standardisasi Permendikbud yang dimaksud. Acuan lainnya yaitu UKBI (Uji Kemahiran Bahasa Indonesia).

Dalam setiap tingkatan BIPA, diajarkan empat keterampilan berbahasa. Empat keterampilan tersebut memiliki proses yang saling terkait dan berurutan mulai dari menyimak, berbicara, membaca, dan menulis. Dalam kaitannya dengan keterampilan membaca, keterampilan membaca merupakan salah satu keterampilan yang sangat penting untuk dikembangkan karena membaca merupakan kunci gudang ilmu (Tarigan, 1986). Posisi keterampilan membaca ini menduduki posisi vital dalam keberhasilan suatu pencapaian hasil belajar sehingga perlu mendapat perhatian khusus (Sudiana, 2007).

Siswa BIPA kelas paling rendah disebut dengan tingkat A1. Siswa pada tingkat ini memiliki kemampuan berbahasa Indonesia yang masih pada tingkat nol. Oleh karena itu, perlu dirancang pembelajaran membaca secara khusus. Membaca merupakan keterampilan yang harus dikuasai pertama sebelum mempelajari keterampilan aktif produktif. Selain itu, posisi membaca sebagai tahap permulaan sangat vital dalam kaitannya dengan pengajaran bahasa kedua pada tahap awal.

Dalam kaitannya dengan pembelajaran bahasa kedua, terdapat tantangan tersendiri dalam penggunaan bahasa target sebagai bahasa pengantar sehingga sedikit atau banyak guru masih memerlukan bantuan dari bahasa pertama siswa untuk dapat menyampaikan materi ajar. Dalam pendekatan deduktif, penggunan bahasa target masih harus dibatasi karena agak sulit menggunakan bahasa target sehinggga masih perlu dibantu dengan bahasa asli siswa, serta adanya ketidakteraturan dalam berlatih 
menerjemahkan kalimat dari bahasa target ke bahasa ibu siswa (Hmedan \& Nafi, 2016).

Dengan berlandaskan pada pendapat tersebut, maka jelaslah meski dalam konteks pengajaran BIPA di mana bahasa Indonesia menjadi bahasa target, penggunannya tidak dapat diberikan secara bertubi dan tiba-tiba dalam jumlah yang signifikan karena dapat memberikan efek kejut pada siswa.

Mengingat siswa SD masuk dalam kategori anak-anak (Riley, 2006) maka penguasaan bahasa kedua anak-anak berproses jauh lebih mudah melalui peniruan. Dengan demikian, pendekatan deduktif dapat menjawab tantangantantangan tersebut. Maka analisis kebutuhan yang dilakukan ini dispesifikkan pada analisis kebutuhan materi ajar membaca BIPA A1 dengan pendekatan deduktif.

Pendekatan deduktif merupakan proses penalaran yang bermula dari keadaan umum ke khusus. Sebagai pendekatan pengajaran, bermula dari menyajikan aturan, prinsip umum yang disertai contoh-contoh khusus atau penerapan aturan. Lebih lanjut, dipaparkan langkah-langkah dalam menuangkan pendekatan deduktif ke dalam materi ajar dapat menempuh langkahlangkah berikut: 1) memilih konsep, prinsip, aturan yang akan disajikan, 2) menyajikan konsep, prinsip, dan aturan yang bersifat umum lengkap dengan definisinya, 3) menyajikan contoh-contoh khusus yang sesuai dengan konsep yang telah dipaparkan, dan 4) menyajikan bukti-bukti yang menunjang (Sagala, 2008).

Analisis kebutuhan merupakan merupakan kegiatan mengidentifikasi unsur-unsur kebahasaan yang dibutuhkan siswa saat siswa diharuskan untuk memahami dan menggunakan bahasa target (Brown, 1995). Yang dimaksud bahasa target yaitu bahasa yang sedang dipelajari siswa yang bukan merupakan bahasa ibunya. Analisis kebutuhan ini menjadi penting karena merupakan salah satu asumsi dasar dari pengembangan kurikulum. Analisis kebutuhan adalah prosedur yang digunakan untuk mengumpulkan informasi mengenai kebutuhan siswa. Dalam hal ini, tujuan yang ingin dicapai selama proses pembelajaran, kemampuan siswa, serta alasan siswa mengikuti program pembelajaran perlu diketahui (Richards, 2005).

Analisis kebutuhan juga merupakan hal krusial dalam pengembangan materi ajar karena jika analisis terhadap guru, siswa, orang tua siswa, dan pihak administratif sekolah gagal dilakukan, produksi materi ajar yang tepat tidak akan pernah terlaksana. Pihak yang terlibat utamanya ialah guru dan siswa. Sebenarnya, sangat memungkinkan bagi guru untuk melakukan analisis kebutuhan di setiap kegiatan pembelajaran, baik secara langsung maupun tidak (Darici, 2000). Diperjelas lagi oleh Darici dengan mengutip Nation dan Macalister bahwa pihak-pihak utama yang terlibat yaitu tiga pihak, siswa, guru, dan pihak manajemen sekolah. Adapun dimensi-dimensi yang digali seputar kebutuhan personal, kebutuhan profesional, dan kebutuhan institusi. Berdasarkan paparan masalah tersebut, maka perlu dilakukan sebuah penelitian yang berkaitan dengan analisis kebutuhan terhadap materi ajar membaca bagi siswa BIPA A1 di D'Royal Moroco Integrative Islamic School.

\section{METODE}

Penelitian ini merupakan tahapan eksplorasi dari penelitian pengembangan Borg dan Gall (1983). Tahapan eksplorasi ini dibagi menjadi tiga tahapan utama, yaitu: pertama, menggali teori yang berkaitan dengan BIPA, pengajaran keterampilan membaca, materi ajar, dan pendekatan deduktif. Kedua, melakukan pengambilan data berupa analisis kebutuhan yang mengacu pada analisis kebutuhan Darici. Analisis kebutuhan dilakukan terhadap seluruh pengajar bahasa Indonesia, seluruh siswa BIPA tingkat $\mathrm{A} 1$, dan pihak sekolah terkait pengajaran membaca bagi siswa BIPA di sekolah tersebut. Pengambilan data dilakukan di SD D'Royal Moroco Integrative Islamic School dengan cara observasi untuk tahapan pendahuluan, analisis dokumen untuk mengetahui kondisi materi ajar yang digunakan selama ini, wawancara untuk menganalisis kebutuhan guru dan institusi. Khusus untuk siswa, digunakan sistem tes untuk mengetahui kebutuhan siswa BIPA di sekolah tersebut. Ketiga, membuat kesimpulan mengenai hasil analisis kebutuhan yang dilakukan untuk dijadikan pijakan dalam mengembangkan silabus dan materi ajar.

\section{HASIL DAN PEMBAHASAN}

\subsection{Analisis Kebutuhan Pengajar}

Wawancara dilakukan terhadap semua pengajar bahasa Indonesia yang merangkap sebagai guru kelas, mulai dari kelas 1 sampai dengan kelas 4. Adapun guru bahasa Indonesia kelas 5 dan 6 yang merupakan guru bidang studi 
bahasa Indonesia dan bukan guru kelas, yaitu peneliti sendiri. Total jumlah guru sebanyak 6 orang yang terdiri atas: 1 orang guru kelas 1,1 orang guru kelas 2,1 orang guru kelas 3, 2 orang guru dari kelas $4 \mathrm{~A}$ dan $4 \mathrm{~B}$, dan 1 orang guru bahasa Indonesia untuk kelas 5A, 5B, dan kelas 6.

Berdasarkan hasil wawancara yang dilakukan, diperoleh data personal seluruh pengajar bahasa Indonesia. Data tersebut terdeskripsikan sebagai berikut: 1) semua pengajar berjenis kelamin perempuan, berusia antara 26 hingga 37 tahun , 2) pengalaman mengajar semua pengajar lebih dari 2 tahun, 3) semua pengajar bahasa Indonesia pada Sekolah Dasar tersebut merupakan Warga Negara Indonesia, dan 3) minat mengajar setiap pengajar bervariasi, pengajar kelas 1 paling meminati pengajaran matematika, pengajar kelas 2 dan kelas 4A paling meminati pengajaran seni rupa, pengajar kelas 3 dan $4 B$ paling meminati bidang studi Bahasa Inggris, dan pengajar bahasa Indonesia untuk kelas 5A, $5 \mathrm{~B}$, dan kelas 6 paling meminati bidang studi Bahasa Indonesia.

Data kebutuhan profesional terdeskripsikan sebagai berikut: 1) semua pengajar memiliki latar belakang Strata 1 dari berbagai bidang keilmuan, antara lain: pendidikan bahasa dan sastra Indonesia sebanyak 1 pengajar, pendidikan bahasa Inggris sebanyak 3 pengajar, sastra Mandarin sebanyak 1 pengajar, dan teknik informatika sebanyak 1 pengajar, 2) semua pengajar menguasai bahasa Indonesia dan bahasa Inggris dengan baik, namun 2 diantaranya juga menguasai bahasa Arab dan 1 diantaranya juga menguasai bahasa Mandarin, 3) dalam mengajar, semua guru memiliki gaya mengajar yang bervariasi, tergantung dari topik yang diajarkan dan situasi kelas saat pengajaran berlangsung, namun secara umum pengajaran masih terpusat kepada guru karena para siswa BIPA memiliki kosakata yang sangat terbatas sehingga guru selalu siap untuk membantu terutama dengan keadaan kelas yang sangat heterogen di mana pengajaran bahasa Indonesia antara siswa BIPA dan nonBIPA dilakukan di kelas yang sama 4) semua guru pernah mengikuti pelatihan guru yang diselenggarakan oleh Marshall Cavendish Education sebuah lembaga dari Singapura. Akan tetapi, pelatihan hanya diselenggarakan untuk 3 bidang studi, yakni Matematika, Sains, dan Bahasa Inggris. Tidak terdapat pelatihan untuk bidang studi lain dalam pelatihan tersebut.

Persentase guru yang menyatakan setuju bahwa perlu disusun materi ajar membaca khusus BIPA pemula yakni mencapai $100 \%$. Topik-topik yang ditanyakan dalam wawancara menggunakan pedoman analisis kebutuhan
Darici yang berkaitan dengan dimensi kebutuhan personal. Di samping itu, digali pula. Sebagai tambahan, ditanyakan pula harapan materi ajar yang diinginkan, dan topik-topik yang dipilih oleh para pengajar ialah sebagai berikut:

Tabel 1. Topik Pilihan Pengajar

\begin{tabular}{|c|c|c|}
\hline $\begin{array}{l}\text { Topik yang } \\
\text { Diusulkan }\end{array}$ & $\begin{array}{c}\text { Pemilih } \\
(\%)\end{array}$ & Keterangan \\
\hline Perkenalan & 100 & Digunakan \\
\hline Kegiatan di sekolah & 100 & Digunakan \\
\hline Kegiatan sehari-hari & 50 & $\begin{array}{l}\text { Dipertimba } \\
\text { ngkan }\end{array}$ \\
\hline Lingkungan rumah & 100 & Digunakan \\
\hline Hobi & 100 & Digunakan \\
\hline Ulang tahun & 83 & Digunakan \\
\hline Transportasi & 83 & Digunakan \\
\hline Liburan & 100 & Digunakan \\
\hline Jual beli & 50 & $\begin{array}{c}\text { Dipertimba } \\
\text { ngkan }\end{array}$ \\
\hline Tempat umum & 66 & Digunakan \\
\hline Kekerabatan & 16 & $\begin{array}{c}\text { Tidak } \\
\text { digunakan }\end{array}$ \\
\hline Warisan budaya & 50 & $\begin{array}{c}\text { Dipertimba } \\
\text { ngkan }\end{array}$ \\
\hline Lingkungan alam & 16 & $\begin{array}{c}\text { Tidak } \\
\text { digunakan }\end{array}$ \\
\hline Kesehatan & 33 & $\begin{array}{c}\text { Tidak } \\
\text { digunakan }\end{array}$ \\
\hline
\end{tabular}

\subsection{Analisis Kebutuhan Siswa}

Tes diberikan pada seluruh siswa dengan jumlah total sebanyak 89 siswa, mulai dari kelas 1 sampai dengan kelas 6 untuk mengetahui secara signifikan jumlah siswa BIPA di sekolah tersebut. Adapun bahan yang diujikan sangat sederhana yaitu topik-topik yang memang ada dalam materi ajar BIPA tingkat A1 mengenai hal-hal yang menyangkut diri sendiri seperti perkenalan yang terkait dengan identitas diri, dan ciri-ciri fisik. Apabila hasil yang diperoleh siswa kurang dari 50\% dari total jumlah butir soal yang ditanyakan, maka siswa tersebut diklasifikasikan dalam kategori BIPA A1.

Berdasarkan hasil tes yang dilakukan terhadap 89 siswa di sekolah tersebut, ditemukan sebanyak 31 siswa atau setara $27,7 \%$ merupakan siswa BIPA tingkat A1, 8,8\% merupakan siswa BIPA tingkat lebih tinggi dan yang sisanya merupakan siswa nonBIPA. Dalam proses penggalian informasi berkaitan 
dengan analisis kebutuhan siswa, tidak dilakukan teknik wawancara maupun angket untuk mengetahui topik-topik apa saja yang diinginkan siswa. Hal tersebut disebabkan oleh sangat terbatasnya penguasaan siswa BIPA tingkat A1 terhadap bahasa Indonesia sehingga wawancara dan angket tidak mungkin dilakukan. Sebagai tindak lanjut dari hasil tes, dilakukan wawancara terhadap pengajar untuk menggali lebih dalam mengenai kesulitan siswa BIPA dalam mempelajari bahasa Indonesia di kelas. Dipaparkan oleh para pengajar bahwa kesulitan-kesulitan siswa antara lain terdapat pada pelafalan, penguasaan kosakata, dan kemampuan menyusun kalimat.

Berkaitan dengan pelafalan, masalah yang ditemukan berupa kesulitan siswa dalam melafalkan gabungan huruf konsonan seperti $n g$, $n y, k h$ dan sebagainya dengan demikian dapat dikatakan bahwa masalah masih muncul pada tataran fonologi. Selain itu, kesulitan juga masih terdapat pada bagian ejaan. Masih banyak siswa yang sulit melafalkan secara tepat kata-kata yang ingin mereka lihat maupun kata-kata yang didiktekan oleh guru. Masalah lain yang juga muncul ditemukan dalam aspek yang berbeda, yakni pada struktur bahasa dan penguasaan kosakata. Siswa mengalami kesulitan saat harus menyusun sebuah kalimat sederhana secara utuh. Hal-hal tersebut terkait erat dengan keterampilan membaca. Sehingga kebutuhan materi ajar membaca BIPA sangat mendesak untuk segera diadakan.

Tabel 2. Kondisi Siswa SD D’Royal Moroco

\begin{tabular}{cccc}
\hline Kelas & $\begin{array}{c}\text { Jumlah } \\
\text { siswa } \\
\text { BIPA A1 } \\
(\%)\end{array}$ & $\begin{array}{c}\text { Jumlah } \\
\text { siswa } \\
\text { BIPA } \\
\text { tingkat } \\
\text { lain (\%) }\end{array}$ & $\begin{array}{c}\text { Jumlah } \\
\text { siswa non } \\
\text { BIPA } \\
(\%)\end{array}$ \\
\hline 1 & 8,9 & 0 & 5,6 \\
2 & 3,4 & 0 & 2,2 \\
3 & 3,3 & 4,4 & 5,6 \\
4A & 3,3 & 2,2 & 8,9 \\
4B & 4,4 & 2,2 & 7,7 \\
5A & 0 & 0 & 11,2 \\
5B & 2,2 & 0 & 10 \\
6 & 2,2 & 0 & 12,3 \\
\hline & 27,7 & 8,8 & 63,5
\end{tabular}

\subsection{Kebutuhan Pihak Sekolah}

Wawancara dilakukan terhadap wakil kepala sekolah bagian kurikulum untuk tingkat SD. Dimensi yang ditanyakan dalam wawancara mencakup dimensi kebutuhan institusi. diperoleh keterangan sebagai berikut: 1) Pihak sekolah mengharapkan arah pengajaran bahasa Indonesia dapat sejalan dengan tuntutan Ujian Nasional. Meskipun cukup banyak siswa yang tidak mahir berbahasa Indonesia, namun sebagian besar siswa di sekolah tersebut merupakan warga negara Indonesia yang pada akhirnya akan mengikuti Ujian Nasional ataupun kejar paket A. Pihak sekolah juga mengharapkan agar para siswa dapat meraih hasil Ujian Nasional yang memadai, walau bagaimana pun Ujian Nasional tetap memiliki persentase nilai dalam kelulusan meski tidak menentukan kelulusan secara penuh. 2) Dari segman pasar, yang diunggulkan sekolah tersebut terletak pada kurikulum Singapura untuk bidang studi selain bahasa Indonesia, serta pengajaran dan lingkungan sekolah juga menggunakan bahasa Inggris. Selain itu, dengan mengitegrasikan kurikulum keislaman yang terejawantahkan dalam bidang studi tahsin, tahfizh, pendidikan agama islam, dan bahasa Arab juga menjadi hal yang diunggulkan sekolah. Segmen pasar untuk bahasa Indonesia dititikberatkan pada nilai Ujian Nasional yang diharapkan mampu bersaing dengan sekolahsekolah nasional. 3) Bahasa Indonesia, tidak diwajibkan untuk dipelajari oleh siswa berkewarganegaraan asing, namun di sekolah ini, bahasa Indonesia diajarkan secara menyeluruh di tingkat SD. Kurikulum yang digunakan yaitu KTSP untuk setiap jenjang. Hanya saja, untuk siswa berkewarganegaraan asing, tidak diwajibkan mengikuti Ujian Nasional, dan selama ini siswa-siswa berkewarganegaraan asing di sekolah tersebut memang belum pernah ada yang mengikuti Ujian Nasional. 4) Keterbatasan sumber daya pengajar dengan latar belakang keilmuan bahasa Indonesia dialami sekolah ini. Sekolah ini hanya memiliki satu pengajar dengan latar belakang Pendidikan Bahasa dan Sastra Indonesia. Pengajar tersebut merupakan peneliti sendiri yang pada tahun ajaran 2015-2016 ditempatkan untuk mengajar bidang studi Bahasa Indonesia di jenjang SD untuk kelas 3 sampai 6. Pada tahun ajaran 20162017 ditempatkan kelas 4 sampai kelas 6. Adapun untuk tahun ajaran 2017-2018 pengajar tersebut ditempatkan di jenjang SD untuk kelas 5 dan 6.

Berdasarkan hasil wawancara diketahui bahwa pihak sekolah setuju mengenai perlunya penyusunan materi ajar membaca khusus BIPA pemula.

\subsection{Kondisi Materi Ajar yang Selama ini Digunakan}

Berdasarkan analisis dokumen yang dilakukan, ditemukan bahwa sekolah tersebut tidak memiliki silabus maupun materi ajar BIPA. Selama ini sekolah tersebut tidak menggunakan materi ajar khusus BIPA, 
melainkan hanya materi ajar bahasa Indonesia untuk penutur asli bahasa Indonesia. Buku ajar tersebut merupakan buku terbitan Yudhistira tahun 2016 dengan menggunakan kurikulum KTSP.

\subsection{Pengembangan Materi Ajar Berdasarkan Hasil Analisis Kebutuhan}

Hal ini akan menjadi catatan penting bagi peneliti untuk menyusun silabus khusus BIPA A1 sebelum mengembangkan materi ajarnya. Silabus yang akan dikembangkan akan mendeskripsikan beberapa komponen antara lain Standar Kompetensi, Kompetensi Dasar, indikator, judul bab, materi pokok, kegiatan pembelajaran, dan evaluasi.

Di samping itu, materi ajar membaca khusus BIPA A1 juga akan dikembangkan. Materi ajar yang ditawarkan berupa buku teks. Penyusunan materi ajar akan menggunakan pendekatan deduktif, yaitu pendekatan yang menyediakan konsep kaidah pada bagian awal setiap materi, menyajikan contoh-contoh relevan berdasarkan kaidah yang telah dipaparkan, dan memuat latihan-latihan yang memadai dalam bentuk aktivitas-aktivitas yang dapat dikerjakan siswa berlatih sesuai topik yang dipelajari. Dalam kaitannya dengan penggunaan materi bagi siswa SD yang masih tergolong anak-anak, maka materi ajar yang dikembangkan juga harus memuat banyak ilustrasi yang menarik. Materi-materi tersebut akan dikemas dalam topik-topik sebagai berikut:

1. Perkenalan

2. Kegiatan di sekolah

3. Lingkungan Rumah

4. Hobi

5. Ulang Tahun

6. Transportasi

7. Liburan

8. Tempat Umum

Topik yang masuk dalam kategori dipertimbangkan, akan menjadi sisipan konten yang diintegrasikan dengan topik lain. Ditambah dengan bab Pra Pengajaran yang dipelajari sebelum masuk pada bab pertama. Hal ini bertujuan untuk melatih pelafalan siswa terhadap huruf, suku kata, dan kata dalam bahasa Indonesia. Termasuk juga pengetahuan tentang membaca angka diajarkan setelah pengajaran huruf. Keduanya, masuk dalam bab Pra Pengajaran.

Pemilihan topik-topik tersebut selanjutnya akan diurutkan mulai dari yang termudah hingga ke yang sulit. Topik-topik tersebut akan dikemas dalam bab-bab yang selanjutnya akan diintegrasikan dengan unsur kebahasaan dan konten budaya Indonesia yang sesuai. Misalnya saat mempelajari teks jadwal dan menu, wawasan ke-Indonesia-an yang akan disisipkan mengenai makanan tradisional Indonesia. Adapun untuk topik-topik lain menyesuaikan.

\section{KESIMPULAN}

Berdasarkan temuan dari hasil analisis kebutuhan dan pembahasan, maka dapat disimpulkan bahwa pengembangan materi yang paling mendesak dibutuhkan ialah materi ajar membaca untuk BIPA A1. Materi ajar akan dikembangkan berbentuk buku teks yang menggunakan pendekatan deduktif, yang memuat: 1) kaidah pada bagian awal, 2) diikuti contoh-contoh relevan, dan 3) latihan yang memadai. Nama lain dari pendekatan deduktif yaitu pendekatan tradisional yang pengajarannya masih berpusat pada guru. Pemilihan bentuk materi ajar berupa buku teks sesuai dengan konsep tersebut.

Pendekatan deduktif menjadi pendekatan paling relevan karena berkaitan dengan pengguna materi ajar yang merupakan siswa BIPA A1, yaitu siswa yang memiliki kemampuan bahasa Indonesia nol atau paling awal. Dalam kaitannya dengan penggunaan materi bagi siswa SD yang masih tergolong anak-anak, maka materi ajar yang dikembangkan juga harus memuat ilustrasi yang menarik. Pada anak-anak, proses belajar yang paling efektif yaitu dengan cara meniru sehingga penyajian materi ajar yang diperkaya konsep, contoh sebelum aktivitas latihan untuk siswa, dan ilustrasi menarik akan membantu siswa. Selain itu, siswa BIPA A1 belum dapat dilepas untuk belajar secara mandiri sehingga masih sangat membutuhkan peran pengajar.

Penelitian ini masih dalam tahap eksplorasi, yaitu tahap analisis kebutuhan. Oleh karena itu, penelitian ini masih perlu dilanjutkan dengan penyusunan silabus dan materi ajar sebagaimana dipaparkan di atas. Setelah lengkap dan sempurna prototipe yang dikembangkan, barulah diuji validasi oleh pakar. Pakar yang dilibatkan dalam hal ini ada 3 yaitu: 1) pakar BIPA, 2) pakar kurikulum, dan 3) pakar pengembangan. Selanjutnya, mengikuti alur penelitian pengembangan yang digunakan.

\section{UCAPAN TERIMA KASIH}

Peneliti menyampaikan ucapan terima kasih kepada LPDP (Lembaga Pengelola Dana Pendidikan) selaku pemberi sponsor sehingga penelitian ini dapat dilakukan dan akan terlaksana secara penuh. Ucapan terima kasih juga disampaikan kepada Universitas Negeri Jakarta sebagai lembaga legalisasi penelitian, Sekolah Dasar D'Royal Moroco Integrative Islamic School atas pemberian izin untuk dapat 
melakukan penelitian di sekolah tersebut, dan tim redaksi Jurnal Pembelajar atas saran dan masukan untuk perbaikan penulisan artikel ini.

\section{DAFTAR RUJUKAN}

Brown, James Dean., (1995). The Elements of Language Curriculum: A Systematic Approach to Program Development (hal. 20, 139). Boston: Heinle\&Heinle.

Darici, Alper., (2016). The Importance of Needs Analysis in Materials Development In M. Azernoosh et al., Issues in Materials Teaching (hal. 30). Rotterdam: Sense Publishers.

Hmedan, Heba Ali Amer \& Nafi, Jamal Subhi Ismail., (2016). The Effect of Using Inductive and Deductive Methods on $7^{\text {th }}$ Grade Students Achievement in Grammar in Bethlehem District and their Attitude toward EFL. International Journal of Education and Social Science, 3(9), 38-53.

Gall, Meredith D., \& Borg, Walter R., (1983). Educational Research: An Introduction (hal. 569). New York: Longman.
Richards, Jack C., (2005). Curriculum Development in Language Teaching (hal. 51). New York: Cambridge University Press.

Riley, Jeni., (2006). Language and Literacy 3-7: Creative Approach to Teaching (hal. 233). London: SAGE Publication

Rivai, et. al., (2010). Pemetaan Pengajaran Bahasa Indonesia bagi Penutur Asing (BIPA) di Asia. Retrived from http://km.ristek.go.id/assets/files/125Pen didikan/BIPAdiAssia/BIPAdiAsia.pdf.

Sagala, Syaiful., (2008). Konsep dan Makna Pemelajaran (hal. 76). Bandung: Alfabeta.

Sudiana, I Nyoman., (2007). Membaca (hal. 2). Malang: UM Press.

Tarigan, Henry Guntur., (1986). Teknik Pengajaran Keterampilan Berbahasa (hal. 135). Bandung: Angkasa. 